\title{
Søvn på dagsorden
}

Intensivsykepleieren har et stort ansvar for å ivareta

intensivpasientens søvnkvalitet. Mange av de foreslåtte endringene er enkle, og overførbare til praksis.

\section{Forfattere}

Inger-Lise Stene-Nilssen

intensivsykepleier, Sykehuset Østfold

Therese Bro

intensivsykepleier, Sykehuset Østfold

Fang Reitan

intensivsykepleier, Sykehuset Østfold

Ann-Cathrin Linqvist Leonardsen

anestesisykepleier, PhD-stipendiat og redaktør

\section{Nøkkelord}

Intensivpasient intensivsykepleier Søvn

Sykepleien 2017 105(61781)(e-61781)

DOI: https://doi.org/10.4220/Sykepleiens.2017.61781

\section{HOVEDBUDSKAP}

Intensivpasienten er utsatt for risiko for dårlig søvnkvalitet, og intensivsykepleiere kan ved relativt enkle tiltak bidra til å fremme søvnkvaliteten. Dempet belysning, bruk av klokke, det å skjerme pasienten og økt «hands-off»-tid er forslag til slike tiltak.

\section{Innledning}


Mangel på søvn hos friske personer har en lang rekke negative konsekvenser som blant annet negativ nitrogenbalanse, nedsatt immunforsvar, økt oksygenforbruk, økt CO2-produksjon og nedsatt utholdenhet av respirasjonsmusklene. Mangel på søvn antas også å medvirke til utvikling av delirium (1). I senere tid sees en økende trend blant helsepersonell hvor man ønsker at intensivpasienten skal være lettere sedert enn tidligere for å redusere antall respiratordøgn. Dette kan medføre at søvn lettere forstyrres, med hyppige oppvåkninger. Det kan se ut til at intensivpasienten tilbringer kortere tid i de restituerende søvnfasene enn friske personer. Det er lite forskning på hvilken betydning disse søvnforstyrrelsene kan ha for intensivpasienten.

\section{Søvnkvalitet}

Søvn deles inn i rapid eye movement (REM) og NonREM sykluser. Når vi sover går vi gjennom 5 forskjellige søvnstadier: Non-REM som er fase 1, 2, 3, 4 og REM. Voksne bruker nesten 50 prosent av sin TST (Total Sleep Time - total søvn tid) i fase 2, nesten 20 prosent i REM-søvn og de siste 30 prosent i de andre fasene. Barn bruker lengre tid i REM-søvn, og eldre bruker mindre (2). 
Fase 1 er lett søvn. I denne fasen går vi inn i søvnen og kan vekkes lett. Øynene beveger seg sakte og muskelaktiviteten roer seg. Respirasjonsdriven reduseres og pustefrekvensen er uregelmessig. I fase 2 stopper øyebevegelsene opp og hjernebølgene blir roligere. I fase 3 har vi ekstremt rolige hjernebølger som også blir omtalt som slow wave sleep (SWS). I fase 4 er det kun SWS. Fase 3 og 4 har man den dype restituerende søvnen. I disse to fasene er det vanskelig å vekke personen. Under SWS er det ingen øyebevegelse eller muskelaktivitet.

Respirasjonsarbeidet blir roligere, og tidalvolumet faller med cirka 13 prosent. Dette resulterer i en normal økning av PaCO2 fra 4-6 mm Hg fra normalverdien og en senkning av pH mellom 0,0030,005 enheter igjennom natten.

\section{三 «SWS- og REM-søvnen blir ansett for å være de restituerende fasene av søvnen.»}

Under REM-søvn begynner vi å puste fortere, øynene beveger seg raskere og hjertefrekvensen og blodtrykk øker. Hvis man våkner under REM-søvnen kan man huske rare drømmer (2, 3). SWS- og REM-søvnen blir ansett for å være de restituerende fasene av søvnen, der den dype søvnen blir ansett for å være den viktigste perioden. Derfor sørger hjernen for at vi er mest i den dype søvnen i starten av natten (3). Hos en intensivpasient er det mange faktorer som direkte forstyrrer søvnen. De kan deles inn i indre og ytre faktorer: Indre faktorer er «the circadian rhythm» (døgnrytme), alder, medisiner, underliggende sykdom, smerte/ubehag og angst (3). 
Ytre faktorer som forstyrrer intensivpasientens søvn er støy fra medisinteknisk utstyr og ansatte, lys som påvirker melatoninproduksjon og hyppig berøring fra ansatte (3). Søvnmangel har flere uheldige konsekvenser og intensivpasienten er spesielt utsatt. Den restituerende effekten av søvn er svært viktig. Mangel på søvn hos intensivpasienter kan føre til komplisert rehabilitering, langvarig sykdom og psykisk stress som delir og posttraumatisk stressyndrom (PTSD) (4).

\section{Støyforstyrrelser}

Støynivået på en intensivavdeling ligger mellom 5085 desibels ( $\mathrm{dB}$ ) (3). Ifølge forurensningsforskriften bør innendørs støy ikke overstige mer enn 35 dB/24 timer (5). Årsakene til støy på intensivavdelingen er oftest knyttet opp mot utstyr som respiratorer, alarmer, overvåkningsutstyr og ansatte som prater. Ørepropper til intensivpasienten for å redusere støy er lite brukt i norske intensivavdelinger, men noe litteratur sier at dette kan hjelpe til med å minske søvnforstyrrelsene (3).

Kritisk syke pasienter krever konstant observasjon og behandling både dag og natt. Livreddende sykepleietiltak går foran tilrettelegging av ro og søvn. Intensivpasienten blir stadig utsatt for fysisk berøring under ulike prosedyrer noe som forstyrrer søvnen. Sykepleietiltak på nattetid blir utført like hyppig som på dagtid. Dette går utover den viktige restituerende nattesøvnen til intensivpasienten (3).

\section{Sykdommer}


Mange kritisk syke pasienter kommer med akutt respirasjonssvikt på grunn av kardiopulmonell sykdom som hjertesvikt, hjerteinfarkt eller kronisk obstruktiv lungesykdom, og har i utgangspunktet svekket det normale søvnmønsteret. Større kirurgiske inngrep viser seg også å være søvnforstyrrende, med negativ effekt på REM-søvn. Videre stabilisering av pasienten krever ofte at de blir sedert og lagt på respirator. Mange av disse sykdommene gir store smerter og ubehag hos pasienten, noe de ofte ikke klarer å fortelle eller uttrykke. Det kan ofte sees med kliniske parametere, men kan også være vanskelig for helsepersonell å oppdage. Dette kan være angstfremkallende for intensivpasienten og kan sørge for å redusere søvnkvaliteten (3).

Infeksjoner i kroppen gjør oss naturlig trøtte. Immunsystemet produserer cytokiner under infeksjon som trolig har en sterk søvnpåvirkende effekt. Søvn kan hjelpe kroppen til å lagre energi og andre ressurser som immunsystemet trenger for å angripe infeksjonen (2). Samtidig vil ulike sykdommer som infeksjoner og inflammasjoner påvirke søvnfasene direkte ved å undertrykke SWS og REM. Tidligere studier har funnet at disse dysfunksjonene direkte påvirker døgnrytmen til intensivpasienter (6).

\section{Medikamentpåvirkning}

Flere typer medikamenter som blir brukt til intensivpasienter undertrykker SWS og REM-søvn. Pasienter som sover i lett søvn, er ekstra utsatte for søvnforstyrrelser. Pasienter som er dypt sedert eller i komatøs tilstand blir ofte omtalt som å være i dyp søvn. Til tross for at de ikke kan vekkes, produserer de likevel ikke en slik kompleks hjerneaktivitet som vi ser under normal søvn. I stedet er hjernebølgene veldig sakte, svake og asynkrone (2, 6). 
Den siste tiden har det blitt vanligere for mekanisk ventilerte intensivpasienter å få intermitterende sedasjon fremfor kontinuerlig sedasjon. Det er dermed påvist en økning av den totale søvntiden (TST) og en $ø$ kning av SWS. Det er spekulert i om den økende deltaaktiviteten kan ha vært forårsaket av metabolske prosesser eller medikamentell effekt. Dette indikerer at medikamentell utløst søvn ikke er like restituerende som den normale fysiologiske søvnen (3). Tabell 1 presenterer et kort sammendrag over hvordan de mest brukte intensivmedikamentene påvirker pasientens søvn (effekten gjelder ikke den dypt sederte pasienten).

\section{Tabell 1: Medikamenters påvirkning på søvn}

\begin{tabular}{|c|c|}
\hline Medikamenter & Effekter \\
\hline $\begin{array}{l}\text { Propofol } \\
\text { Fentanyl } \\
\text { Midazolam } \\
\text { Dexmedetomidine } \\
\text { Andreopioider } \\
\text { Andrebenzodiazepiner } \\
\text { Noradrenalin, adrenalin, dopamin } \\
\text { Corticosteroider } \\
\text { Cordarone } \\
\text { Betablokkere } \\
\text { Clonidin }\end{array}$ & $\begin{array}{l}\text { Nedsatt REM- og SWS-faser } \\
\text { Nedsatt REM- og SWS-faser } \\
\text { Nedsatt REM- og SWS-faser } \\
\text { Øker SWS, men setter ned REM-faser } \\
\text { Nedsatt REM- og SWS-faser } \\
\text { Nedsatt REM- og SWS-faser } \\
\text { Insomnia og nedsatt REM- og SWS-fase } \\
\text { Insomnia, nedsatt REM-fase og mareritt } \\
\text { Mareritt } \\
\text { Insomnia, nedsatt REM-fase og mareritt } \\
\text { Nedsatt REM-fase }\end{array}$ \\
\hline
\end{tabular}

Kilde $(1,3,6,7)$

Melatoninsekresjon stimuleres av mørket og hemmes av lysmengde. Maksimum sekresjon av melatonin blir forbundet med fravær av lys, som vanligvis er mellom klokken 21.00-03.00. Hormonsekresjon (som kortisol) og kroppstemperatur er andre eksempler som også påvirker døgnrytmen. Intensivpasienten blir i stor grad eksponert for lys 24 timer i døgnet, og dette hemmer deres produksjon av det søvndyssende hormonet melatonin (8). Mangel på tilstrekkelig melatoninsekresjon kan føre til søvnmangel, spesielt hos intensivpasienten. Tilførsel av melatonin forskyver døgnvariasjonsfasene (3). 
Studier har ikke klart å vise til statistisk signifikant forskjell i total søvn tid eller døgnvariasjon mellom kontroll- og intervensjonsgruppene ved bruk av melatonin hos kritisk syke pasienter til tross for bekreftelse av terapeutiske serumlegemiddelnivåer i intervensjonsgruppen (3).

\section{Målemetoder}

Det finnes flere verktøy for å kartlegge intensivpasientens sedasjonsdybde, men søvnkvaliteten ser ut til å være dårlig kartlagt ved norske intensivavdelinger (4).

Kartleggingsverktøyet Richards-Campbell Sleep Questionnaire (RCSQ) kan brukes til den våkne intensivpasienter. RCSQ baserer seg på 5 områder som søvndybde, innsovning, våkenhet, tilbake til søvn og søvnkvalitet. Dahl et al (4) hevdet at RCSQ er et brukbart verktøy for vurdering av søvn. Svakheten er at det er en subjektiv oppfatning av pasientens søvnkvalitet i motsetning til Polysomnografi (PSG) som måler de faktiske tidene i søvnfasene. RCSQverktøyet kan ifølge Frisk og Nordstøm (9) ikke brukes hos den sederte intensivpasienten, men kan anvendes til våkne intensivpasienter. De hevder også at sykepleiere kan bruke RCSQ til pasienter som ikke klarer å fylle ut skjemaet selv, når årsaken er at de er forvirret eller for trøtte til å svare på spørsmålene på egen hånd.

\section{三 «Polysomnografi (PSG) regnes som gullstandarden for søvnregistrering.»}


Polysomnografi (PSG) regnes som gullstandarden for søvnregistrering. Den måler en rekke fysiologiske parametere under søvn. Gjennom elektroder påsatt på forskjellige steder på kroppen registreres EEG, øyebevegelse, muskelbevegelse, EKG og respirasjon. Dette måles gjennom en hel søvnperiode. Det er ikke lett å utføre polysomnografi som målemetode. Det blir mange ledninger på pasienten, noe som begrenser pasientens bevegelsesfrihet, mobilisering og pleie. I tillegg er det kostbart og ressurskrevende å analysere de registrerte dataene. Ritmala-Castren et al (10) og Cooper et al (11) hevder at PSG-måling i seg selv er søvnforstyrrende og tidkrevende. Det er derfor få og små studier som har anvendt dette $(3,4)$.

\section{Intensivpasientens søvn}

At intensivpasienter opplever søvnforstyrrelser er godt dokumentert $(9,11-14)$. Pasientene opplever ofte å være i en sovende-våken tilstand. De får med seg mye av hva som skjer inne på pasientrommet. Pasienter har beskrevet dette som «å være i en limbo» hvor de lengter etter søvn og hvor de har fått minner og mareritt om oppholdet på intensivavdelingen og har en opplevelse av å være konstant slitne, ofte deprimerte og ute av stand til å føle seg trygg (15). Dahl et al (4) har sett på sykepleieres vurdering av hvordan intensivpasientene sover. Med registrering på en skala fra $0-10$, mente de fleste sykepleiere at intensivpasienter sov moderat.

En studie viste at gjennomsnittlig søvnlengde hos intensivpasienter var på 387 minutter (Non-REM 0\%-42\% og REM 0\%-65\%). Frekvensen mellom oppvåkninger varierte fra 2 til 73 ganger per time. Det ble ikke funnet noen likheter blant pasienter som sover mer enn 7,5 timer ved bruk av smertestillende medikamenter eller noradrenalin. Om dette var en kirurgisk eller medisinsk pasient var heller ikke av betydning. Mye aktivitet rundt pasienten viste mer lett søvn og mindre dyp søvn (10). 
Det kan synes som om de ulike studiene som har målt søvn hos intensivpasienter i ulike grupper har funn som er i overensstemmelse med sykdommens alvorlighetsgrad og sederingsgrad. Teorien om at sykdommens alvorlighetsgrad spiller en stor rolle blir bekreftet av Cooper et al (11) som spekulerer i om sykdom alene kan være årsaken til forstyrrelser i søvnsyklusen. Dette blir derimot avkreftet av RitmalaCastren et al (10) som viser til at pasientene med de mildeste sykdommene hadde flere vekkinger enn de med alvorligere sykdom. De hevdet at de mindre syke var mer sensitive for eksterne stimuli som førte til mer fragmentert søvn. Dette kan forklares med at sykdommer som infeksjoner gjør pasientene mer søvnige. Freedman et al (12) har studert flere pasientgrupper og mener de ikke kan se noen klare mekanismer som årsak til nedsatt REM-søvn.

Et interessant funn fra Frisk\& Nordstrøm (9) er at de pasientene som mottok sedasjon i løpet av natten hevdet selv at de sov dårligere enn de som ikke hadde behov for sedering. En kan spørre seg om dette beror på medikamentets egenskaper. Om pasientene som trenger sedasjon i utgangspunktet ville hatt dårligere søvn? Eller kan det være en kombinasjon av begge deler? Pasientenes erfaringer med å få smertelindring ga de følelsen av å sveve, og dermed ikke klarte å gå videre inn i søvnen Tembo et al (15). Dette sammenfaller med hva litteraturen sier om medikamenters effekt på å undertrykke SWS og REMsøvnen (jf. tabell 1).

\section{Forstyrrelser og begrensninger}


Cooper et al (11) delte pasientene inn i tre grupper etter hvilke søvnfase-funn de fant på PSG-målinger. De hadde alle unormal søvn, men hos pasientgruppen som lå i en komatøs tilstand med 50 prosent SWS, kan man lure på hva slags type søvn dette egentlig er. Hva representerer egentlig denne SWS-fasen? Sedasjon? Patologi og i tilfellet hva? Søvn? Er en kontinuerlig SWS-fase like kvalitativt restituerende som SWS-faser som sees ved normale søvnsykluser? PSG-studier viser unormal søvnsyklus hos denne pasientgruppen. Deltabølgene som sees ved SWS-faser ved både Propofol, Midazolam og Fentanyl er doseavhengig. Lavere doser av disse medikamentene kan gi helt andre typer forandringer, som undertrykkelse av SWS og REM. Altså, kan sedasjon (til deltaaktivitet) være like restituerende som dyp søvn?

Intensivpasienten er en gruppe pasienter som ofte utsettes for mye stimuli. Mange prosedyrer som er nødvendig for pasientens behandling er ubehagelige og smertefulle. Freedman et al (12) hevder at pasienter som mottar mekanisk ventilasjonsstøtte har forstyrrelser i søvnmønsteret, med store individuelle forskjeller. Frisk et al (9) rapporterer at 11 av 16 pasienter har forstyrrelser i form av ubehag, smerter, angst og bekymringer. Skulle pasientene vært bedre smertelindret eller burde man vurdert angstdempende medikamenter for å fremme søvn?

\section{三 «Pasientens tilhelingsprosess reduseres på bakgrunn av frafall av restituerende søvnfaser.»}


Teorien viser at noen medikamenter kan ha

forstyrrende effekt på søvnfaser (jf. tabell 1). Men

ligger pasienten med smerter og engster seg vil dette igjen påvirke om han eller hun i det hele tatt klarer å sove. Det er viktig å ha et fokus som er til det beste for pasienten. Smerter, ubehag og bekymringer kategoriseres også som forstyrrende momenter. Alt dette har en rekke negative konsekvenser på søvnen. Pasientens tilhelingsprosess reduseres på bakgrunn av frafall av restituerende søvnfaser. I studien til Frisk\& Nordstrøm (9) og Little et al (14) mente 48 prosent av pasientene at det ikke var noe spesielt som forstyrret søvnen, mot 52 prosent som mente at ubehag i form av smerte eller angst var mest forstyrrende.

De mest vanlige årsakene til manglende søvnlengde og søvnkvalitet er oppgitt å være støy og lys, sammen med høylytt prat og tidsforvirring (14). RitmalaCastren et al (10) hevder at lys, lyd og berøring ofte vekker pasienten. Det positive ved resultatene er at de mener at sykepleietiltak, som stell, ofte ble utført allerede når pasienten var våken. Likevel har bare 31 prosent av sykepleieaktivitetene intervaller mellom seg på mer enn 90 minutter (10). Freedman et al (12) målte støynivået til å ligge mellom 56-85 dB både dag og natt, noe som er langt høyere enn anbefalingene. Til tross for dette var kun 17 prosent av oppvåkningene forårsaket av støy. Støy viste seg å ha en overraskende lav årsak til søvnforstyrrelser hos intensivpasienten enn hva litteraturen har antatt. Frisk et al (9) bekreftet også at støy ikke er den store søvnforstyrrelsessynderen. Bare 4 av 31 pasienter rapporterte at støy fra medpasienter var forstyrrende. De følte det var et lavt støynivå om natten og at dette ikke var årsaken til at de sov dårlig. Motsatt hevder Tembo et al (15) at pasientene opplevde at de hørte og fikk med seg alt som foregikk i rommet. 
Ifølge Celik et al (13) var aktiviteter som øyestell, munnstell, sårstell, forflytning, bandasjering, stell, vask og kateterbytte hyppigst utført. De fleste forstyrrelsene fant sted på natten mellom klokken 02.00 og 05.00. Det var ingen forskjell å se om pasienten var sedert eller ikke. Sykepleieprosedyrer relatert til smertebehandling, forflytning, påkledning, mating, sondeernæring, lys- og lydrelaterte prosedyrer, medisinering og smerter var årsaker som også gikk igjen. Hos 62 prosent ble det utført fullt stell mellom klokken 02.00-05.00 (13). Selv om en ser at det er mye aktivitet med pasienten på natten, viser Celik et al (13) at størsteparten av sykepleieaktiviteter på intensivavdelingen omhandler aktiviteter som vil øke fysiologisk stabilitet hos pasienten.

Lys justerer døgnrytmen vår. Ved å ikke justere lys i forhold til tiden på døgnet, opprettholdes den forstyrrete døgnrytmen intensivpasienten sliter med. Lys på nattetid forstyrrer søvnkvaliteten til intensivpasienten og ødelegger pasientens normale døgnrytme $(4,12)$. Flere studier har funnet store variasjoner i TST over 24 timer. Videre er det ikke bare søvnen som er forstyrret, men generelt hele døgnrytmen (16).

\section{Bedring av søvn}

Det er mange tiltak intensivsykepleieren kan gjøre for å fremme intensivpasientens søvnkvalitet. Mye lys og aktivitet gjennom hele døgnet gjør at intensivpasienten mister følelsen av når det er natt. Å redusere intensivsykepleiens oppgaver om natten er en del av forebyggende tiltak, men dette forutsetter at intensivpasienten er stabil og kan få «pause» uten at det går utover hans eller hennes behandling og helsetilstand (4). Little et al (14) forsket på ønskelige forbedringstiltak for å redusere søvnforstyrrelse. «Nedtonet lys» var ett av dem. 
Dahl et al (4) mener at hvis sykepleieren er oppmerksom på omgivelsene rundt pasienten, er det mange enkelte tiltak som kan utføres. I dette tilfellet kan intensivsykepleieren dempe taklys og lys fra diverse elektronisk utstyr som monitoreringsskjem, respiratorskjerm og så videre. Selv om dette i seg selv er enkle tiltak, kan det være omstendigheter rundt pasienten som gjør dette vanskelig. Sykepleieren skal kunne se pasienten og elektronisk utstyr for å gjøre nødvendige vurderinger for å observere pasienten. Noe av dette kan være vanskelig å utføre i mørket, men selvfølgelig er det muligheter for å nedjustere lysstyrken.

Ved å bruke klokke kan intensivpasienten få mulighet til å orientere seg. Dette kan gi pasienten kontroll over tiden og hjelpe pasienten med å opprettholde døgnrytmen. Dersom pasienten ikke er i stand til å se seg rundt, blir det ofte orientert om sted, dato og tid på døgnet. Dette kan være en fin måte å orientere pasienten på.

\section{三 «Pasienter bør skjermes fra andre pasienter for å redusere støy og inntrykk.»}

Pasienter bør skjermes fra andre pasienter for å redusere støy og inntrykk (15). Dahl et al (4) hevder at å redusere støy fra personalet er en vanlig intervensjon. Kun 32 prosent av deres respondenter gjorde dette svært ofte og 32 prosent gjorde dette som rutine. Da dette er et tiltak som er lett å utføre og som kan utgjøre store forskjeller for pasientens innemiljø, burde et større antall av intensivsykepleierne ha fokus på dette.

Man kan bruke ørepropper, men ifølge Dahl et al (4) er ørepropper lite bruk på norske intensivavdelinger. Effekten av bruken er lite dokumentert. Videre skriver de at noen av pasienten kan ha en følelse av å være innestengt fra omverden siden de ikke har mulighet å ta ut øreproppene selv. Dette kan resultere i å miste kontroll over seg selv og kan være angstfremmende. 


\section{Hands-off}

Det er registrert opp til 51 sykepleieaktiviteter som nødvendiggjør fysisk kontakt med pasienten på nattetid (13). Det sier ganske mye om grad av forstyrrelser. Hvordan skal pasienten i det hele tatt klare å komme inn i søvnen, når han til stadighet blir tatt på og forstyrret? Dette viser hvor viktig det er å samle aktivitetene i bolker når det er mulig, samtidig som man vurderer hver minste «hands-on» bevegelse om den i det hele tatt er nødvendig. Intensivsykepleieren er vant til å stelle med pasienten, alt skal være i orden, man jobber hele tiden systematisk gjennom pasienten, sørger for at han/hun ligger riktig, dynen skal ikke være skrukkete, det skal se pent og systematisk ut. Noen ganger må man faktisk klare å se på «en rotete» pasientseng for å la pasienten være i ro.

Intensivsykepleieren må huske at det ikke er viktig hvor ryddig det ser ut på rommet som er avgjørende for god sykepleie. Dette støttes av blant annet Dahl et al (4), som viser at sykepleierne velger å forstyrre pasienten for å få sine oppgaver utført og at det er utfordrende å planlegge med å samle opp oppgaver. 
«Hands-off»-praksis på nyfødt intensiv (NFI) er at man ikke skal forstyrre et barn som sover hvis ikke det er strengt tatt nødvendig. De færreste barna på NFI er sedert, noe som kan gjøre det enklere å lese mimikk og ansiktsuttrykk enn hos voksne sederte pasienter. Dette kan være årsak til at det er lettere å ta hensyn til søvn hos denne pasientgruppen. Erfaring tilsier at spesialsykepleiere på NFI har gode holdninger og kunnskap om søvn blant sin pasientgruppe. Spesialsykepleieren har større autoritet på dette området hvor «hands-off»-begrepet blir respektert av barneleger, fysioterapeuter og foreldre. Kan dette være kunnskap intensivsykepleieren kan overføre voksen intensivavdeling? Dette kan bedre tverrfaglige samarbeid med andre faggrupper med fokus på å begrense og samle arbeidsoppgaver for å sørge for minst mulig søvnforstyrrelser og avbrutt søvn.

Kunne man vurdert å lage en søvnfremmende protokoll? Der man som Celik et al (13) anbefaler å ha ekstra fokus på søvn og hviletid, med gitte stilletider, spesielt om natten, som eksempelvis mellom klokken 24.00-05.00 hvor søvn skal fremmes så godt det lar seg gjøre.

\section{Avslutning}

Det er mange faktorer som ødelegger søvnsyklusen til denne pasientgruppen. Intensivsykepleieren har et stort ansvarsområde når det gjelder å ivareta intensivpasientens søvnkvalitet. Mange av de foreslåtte endringene er enkle, og burde være lett å overføre til praksis. Det er et behov for kompetanseheving og bevisstgjøring på dette området, og at søvn må komme på dagsordenen. Søvnen skal være hellig for intensivpasienten og det er intensivsykepleierens ansvar å verne om dette.

\section{Referanse}


1. Dansk Selskap for Intensiv Terapi (DSIT).

Sedasjons strategi. 2010. Tilgjengelig fra:

http://www.dasaim.dk/wp-

content/uploads/2014/02/Sedationsstrategi_samlet...

(nedlastet 19.04.2016).

2. National Institute of Neurological Disorders and

Stroke. Brain Basics: Understanding Sleep.

Tilgjengelig fra:

http://www.ninds.nih.gov/disorders/brain_basics/understanding_sleep.htm\#... (nedlastet 19.04.2016).

3. Goring KL, Collop NA. Sleep Issues in the Intensive Care Unit Setting. I: Rippe JM, Irwin RS. Intensive Care Medicine. Philadelphia; Wolters

Kluwer, Lippincott Wiliams\& Wilkins: 2012.

4. Dahl AF, Foss H, Fossum M. Norske intensivavdelingers praksis rundt søvn og sedasjon. Nordic J Nurs Res 2015;2(25):105-112.

5. Forurensningsforskriften. Forskrift om begrensning av forurensning (forurensningsforskriften). 2004.

Tilgjengelig fra:

https://lovdata.no/dokument/SF/forskrift/2004-06-01931/KAPITTEL_2\#KAPIT... (nedlastet 02.05.2016).

6. Brainard J, Gobel M, Bartels K, Scott B, Koeppen M, Eckle T. Circadian Rhytms in Anestesia and Critical Care Medicine: Potential importance of circadian disruptions. SAGE Journals 2015;19(1):4960.

7. Deleaney LJ, Van F, Lopez V. Sleeping on a problem: the impact of sleep disturbance on intensive care patients-a clinical reviw. Ann Int Care 2015;5(3):1-10.

8. Brodal P. Sentralnervesystemet: Sentrale deler av det autonome nervesystemet. Oslo:

Universitetsforlaget; 2013. 
9. Frisk U, Nordstrøm U. Patients` sleep in an intensive care unit- patients and nurses perception. Int Crit Care Nurs 2003;19:342-349.

10. Ritmala-Castren M, Virtanen I, Leivo S, Kaukonen KM, Leino-Kilpi H. Sleep and nursing care activities in an intensive care unit. Nurs Health Sci 2015;17:354-362.

11. Cooper AB, Thornley G, Young B, Slutsky AS, Stewart TF, Hanly PJ. Sleep in critically ill patients requiring mechanical ventilation. CHEST 2000;117(3):809-818.

12. Freedman NS, Gazendam J, Lachlle P, Schwab RJ. Abnormal Sleep/ Wake Cycles and the Effect of Environmental Noise on Sleep Disruption in the Intensive Care Unit. Am J Resp Crit Care Med 2001;163:451-457.

13. Celik S, Oxtekin D, Akyolcu N, Issever H. Sleep disturbance: The patient care activities applied at the night shift in the intensive care unit. J Clin Nurs 2005;14:102-106.

14. Little A, Ethier C, Ayas N, Thanachanont T, Jiang D, Mehta S. A patient survey of sleep quality in the intensive care unit. Minerva Anestesiologica 2012;78:406-414.

15. Tembo AC, Parker V, Higgins I. The experience of sleep deprivation in intensive care patients: findings from a larger hermeneutic phenomenological study.Int Crit Care Nurs 2013;29(6):310-6.

16. Drouot X, Cabello B, d`Ortho MP, Brochard L. Sleep in the intensive care unit. Sleep Medicine Reviews 2008;12:391-403. 